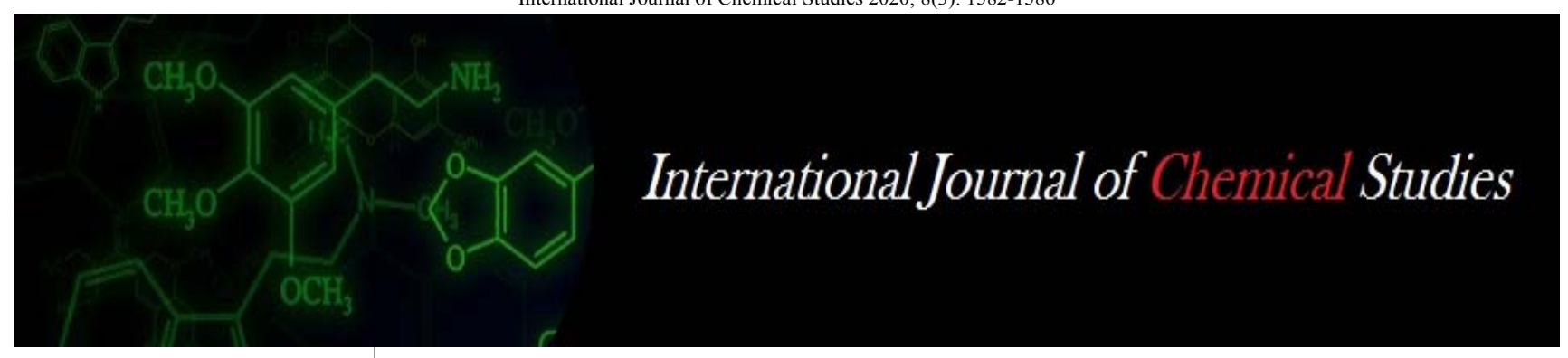

P-ISSN: 2349-8528

E-ISSN: 2321-4902

www.chemijournal.com

IJCS 2020; 8(3): 1582-1586

(C) 2020 IJCS

Received: 26-03-2020

Accepted: 29-04-2020

\section{Ramya VS}

MS. C, Agriculture Sericulture, Department of Sericulture, UAS, GKVK, Bengaluru,

Karnataka, India

\section{Chandrasekhar S}

Professor and Head, Department of Sericulture, UAS, GKVK, Bengaluru, Karnataka, India
Corresponding Author: Ramya VS

MS. C, Agriculture Sericulture, Department of Sericulture, UAS, GKVK, Bengaluru, Karnataka, India

\section{Value added product prepared using mulberry leaves}

\section{Ramya VS and Chandrasekhar S}

DOI: https://doi.org/10.22271/chemi.2020.v8.i3u.9419

Abstract

In the present fast growing rapidly changing global society, attaining good health has become a challenge for all age groups. Now a day's consumption of foods made from the leaves increased, but still, few are considered as wastes, but they are actually beneficial for health. The study was made to utilize mulberry leaves in different form in value-added product, thus reducing the wastage and providing inexpensive, healthy product mulberry leaves contain a good amount of high protein, vitamin $\mathrm{C}$, beta-carotene and calcium contents. It can be easily grown in different parts of India and hence can help to meet the recommended dietary allowance of various micronutrients and improve the health status of vulnerable groups. Four variations of mulberry leaves masala biscuits were developed using mulberry leaves in different proportions viz., 2.5, 5, 7.5, 10 per cent in preparation of chutney powder with other commonly used ingredients. The acceptability of four variations of developed mulberry leaves powder were studied by evaluating different organoleptic characteristics by 21 semi trained panel member. Mulberry leaves powder chutney proportion 2.5 per cent secured highest acceptability scores. Further proportion I was subjected for nutrient and cost analysis.

Keywords: Development of mulberry leaves chutney powder, organoleptic evaluation, nutrient and cost analysis

\section{Introduction}

Mulberry is a perennial woody plant belongs to family Moraceae and genus Morus. It is a fastgrowing deciduous plant that grows well in different climatic conditions (i.e. tropical, subtropical and temperate). It is mainly cultivated for the sericulture industry, as the leaves constitute the only food for silkworm Bombyx mori. (Ramesh et al., 2014). In addition to the major utilization of mulberry leaves as silkworm feed, it is being used for many other purposes, for which it is called as Kalpavriksha and this has opened a new vista to think about other uses of mulberry apart from silkworm feed (Asha et al., 2015).

Mulberry leaves have the enormous medicinal potential and curative properties. The leaves have been reported to be a rich source of $\beta$ carotene, protein, vitamin $C$ and calcium contents act as a good source of natural antioxidant.

Nutritionists are now trying to encourage cultivation and incorporation of GLVs in various recipes with minimum effort and little cost, yielding a great benefit. Devising several simple and acceptable micronutrient rich recipes containing GLVs would not only bring variety to the diet but also helps in combating micronutrient deficiencies. The best method for utilization of the available protein in mulberry is in the form of leaf protein concentration (LPC) which contains carbohydrates, lipids and minerals besides protein as the major constituent. In addition, it contains a fairly good amount of nutritionally important pigments like carotenes and xanthophyll's. Hence, leaf protein is a food, which contains beta-carotene and fat, the precursor of vitamin A, forming an ideal supplement to prevent malnutrition.

Mulberry leaves which are rich in micronutrients but are mostly discarded or go waste were used in traditional Indian recipes and evaluated for their acceptability. A Consumer demands for nutritious, convenient and safe foods is increasing day by day. In determining food consumption and nutrition intake, many of Indian studies focus on food prices, expenditure level, and income and very few of them incorporate regional factor, which not only reflects the distinct production and price pattern but also show sharp cultural differences. In developing countries where most of the people are engulfed in poverty and cannot afford the expensive 
food products and suffer from various deficiency diseases, a need to identify cheap and easily available source rich in micronutrients is essential.

\section{Methodology}

Four variations of mulberry leaves powder chutney one control without mulberry leaf powder were developed by using mulberry leaves powder, Uradh dhal, Chana dhal, Red gram, Ginger, Dry coconut, tamarind (Tamarindus indica) and chilli powder and salt. Developed variations of mulberry leaves chutney powder were evaluated for organoleptic characteristics. Further highly accepted mulberry leaves chutney powder was analyzed for nutrient content and analysed for cost.

\section{Preparation of mulberry leaves powder}

The collected mulberry leaves were manually separated and the leaves were washed in tap water to remove extraneous matter. Fresh leaves were boiled for 5 minutes at $80{ }^{\circ} \mathrm{C}$ where blanching is done to inhibit enzyme activity and then dried in tray drier at $60 \pm 5^{\circ} \mathrm{C}$ for 3 hours.

\section{Development of mulberry leaves chutney powder}

Four variation of mulberry leaves chutney powder and one control without mulberry leaf powder were developed by utilizing selected ingredients with varying amount of mulberry leaves powder, Uradh dhal, Chana dhal, Red gram, Ginger, Dry coconut, tamarind and chilli powder and salt. Table 1.

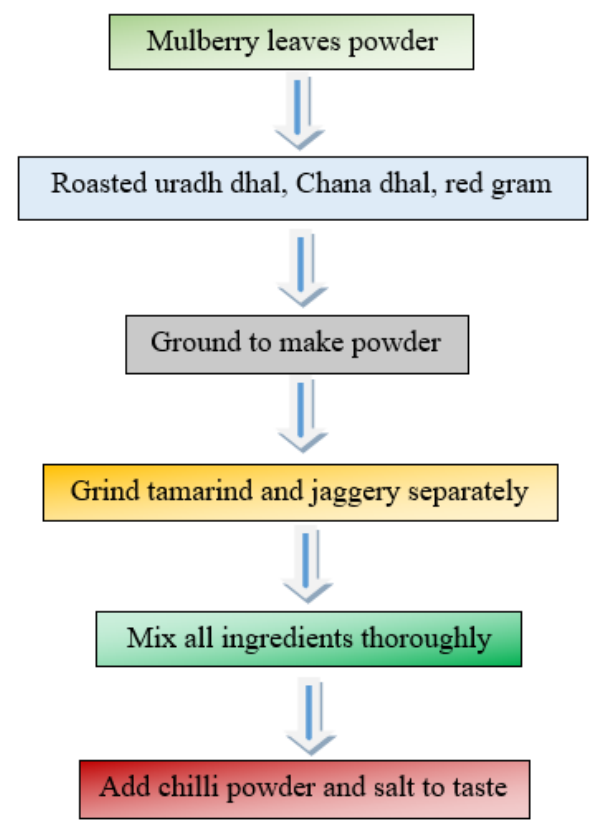

Fig 1: Preparation of chutney powder

Table 1: Ingredients for chutney powder preparation

\begin{tabular}{|c|c|c|c|c|c|c|}
\hline S. No. & Ingredients (g) & I & II & III & IV & Control \\
\hline 1 & Uradh dhal & 30 & 30 & 30 & 30 & 30 \\
\hline 2 & Chana dhal & 30 & 30 & 30 & 30 & 30 \\
\hline 3 & Red gram & 18 & 18 & 18 & 18 & 20 \\
\hline 4 & Dry coconut & 10.5 & 8 & 5.5 & 3 & 11 \\
\hline 5 & Ginger & 2 & 2 & 2 & 2 & 2 \\
\hline 6 & Tamrind & 2 & 2 & 2 & 2 & 2 \\
\hline 7 & Chilli & 3 & 3 & 3 & 3 & 3 \\
\hline 8 & Salt & 2 & 2 & 2 & 2 & 2 \\
\hline 9 & Mulberry leaf & 2.5 & 5 & 7.5 & 10 & - \\
\hline
\end{tabular}

\section{Nutrient analysis}

The nutrient content of highly accepted variation of mulberry leaves powder chutney was analysed. Moisture free sample was used for analysis. The proximate composition (moisture, total protein, fat, fibre and total minerals) was carried out as per procedures prescribed by A.O.A.C. (1975). Carbohydrate content was calculated by difference method. Calcium was estimated by EDTA method. Trace elements (iron, copper, zinc and magnesium) were estimated by Atomic Absorption Spectrophotometer (Perkin R Elmer Model - 3110). The values for all nutrients were averages of triplicate value on dry weight basis.

The data of acceptability of four developed variations of mulberry leaves powder chutney were statistically analysed by one-way analysis of variance and ' $F$ ' values were calculated to find out the difference among the developed variations of herbal composite (Panse and Sukhatme, 1985).

\section{Cost calculation of the developed products}

Cost calculation was done for the best accepted products. This included cost of the ingredients and overhead charges at 30 per cent which include labour charge, electricity, machinery, packaging cost, etc. and then the total price was calculated for $100 \mathrm{~g}$ of the products.

\section{Observations and assessment}

The results obtained from the present investigation as well as relevant discussion have been summarized under following heads:

\section{Organoleptic characteristics of mulberry leaves chutney powder}

Information regarding the general description of development of mulberry leaves chutney powder is given in Table 1. Four variations of mulberry leaves chutney powder were prepared with varying of mulberry leaves powder Uradh dhal, Chana dhal, Red gram, Ginger, Dry coconut, tamarind and chilli powder and salt. The mean values of organoleptic scores for the acceptability of mulberry leaves chutney powder prepared by using varying amount of mulberry leaves and other ingredients. Different sample were given to different levels used in chutney powder so that the levels were not revealed to the panellists to get their exact judgment of the samples. Sensory evaluation of the developed products was carried out to determine the most suitable level of mulberry leaves incorporated in food for each product. The panel was provided 9-point hedonic scale for attributes like appearance, colour, texture, aroma, taste and overall acceptability (Larmond 1970).

\section{Sensory evaluation of Mulberry leaves chutney powder (MLCP)}

The chutney powder was prepared by using mulberry leaves with $2.5,5,7.5$ and 10 per cent incorporation. Products were subjected to sensory evaluation by 21 semi trained panel members using nine-point hedonic scale and the results are presented in Table 2.

The mean score of mulberry leaves chutney powder for appearance ranged from 8 to 8.5 , for colour from 8 to 8.5 , for texture from 7 to 7.5 , for aroma from 7 to 7.5 , for taste ranged from 8 to 8.5 and for overall acceptability it is ranged from 7 to 7.5. The control had highest score for appearance, colour and taste. Whereas texture, flavour and overall acceptability was high in mulberry leaves chutney powder (2.5 per cent). Among four variations of chutney powder, mulberry leaves 
chutney powder (2.5 per cent) scored better in all organoleptic characteristics and the least mean score was recorded in mulberry leaves chutney powder (10 per cent).

\section{Colour and appearance}

All the treatment varied significantly with compared to control with respect to appearance and colour. The maximum score of 8.50 was recorded in control with no mulberry leaf powder incorporation for both appearance and colour followed by the chutney powder with 2.5 per cent mulberry leaf powder with the mean score 8 . The chutney powder with mulberry leaf powder i.e. 5 per cent, 7.5 per cent and 10 per cent incorporation recorded mean score of 7 for each.

\section{Texture, flavour and taste}

The maximum mean score of 7.5 was recorded in the products i.e. 2.5 per cent and 7.5 per cent incorporation of mulberry leaf which is on par with other treatments and also in control. Taste of different chutney powder varied significantly compared to control.

The control treatment (with no mulberry leaf powder incorporation) and the treatment with 10 per cent mulberry leaf powder incorporation scored highest of 8.5 each for taste and followed by the chutney powder with 2.5 per cent mulberry leaf powder incorporation. The lowest sensory score of 7.00 was recorded in the mulberry leaves chutney powder (7.5 per cent).

Table 2: Mean sensory score of mulberry leaves chutney powder (MLCP)

\begin{tabular}{|c|c|c|c|c|c|c|}
\hline \multirow{2}{*}{ Products } & \multicolumn{6}{|c|}{ Sensory attributes } \\
\hline & Appearance & Texture & Colour & Flavour & Taste & Overall acceptability \\
\hline $\operatorname{MLCP}(2.5 \%)$ & $8^{\mathrm{b}}$ & 7.5 & $8^{b}$ & 7.5 & $8^{\mathrm{b}}$ & $7.5^{\mathrm{a}}$ \\
\hline MLCP (5\%) & $7^{\mathrm{c}}$ & 7 & $7.5^{\mathrm{c}}$ & 7 & $7.5^{\mathrm{c}}$ & $7^{b}$ \\
\hline $\operatorname{MLCP}(7.5 \%)$ & $7^{\mathrm{c}}$ & 7.5 & $7^{d}$ & 7.5 & $7^{d}$ & $7.5^{\mathrm{a}}$ \\
\hline MLCP $(10 \%)$ & $7^{c}$ & 7 & $7^{d}$ & 7 & $8.5^{\mathrm{a}}$ & $7^{b}$ \\
\hline Control & $8.5^{\mathrm{a}}$ & 7 & $8.5^{\mathrm{a}}$ & 7 & $8.5^{\mathrm{a}}$ & $7^{b}$ \\
\hline F test & * & NS & * & NS & * & $*$ \\
\hline $\mathrm{SEm} \pm$ & 0.037 & 0.038 & 0.0322 & 0.044 & 0.0278 & 0.0296 \\
\hline CD@5\% & 0.1088 & - & 0.09468 & - & 0.0870 & 0.0870 \\
\hline
\end{tabular}

*Significance, NS- Non significant at 5per cent level, MLCP- Mulberry leaves chutney powder (2.5per cent), MLCP- Mulberry leaves chutney powder (5per cent), MLCP- Mulberry leaves chutney powder (7.5per cent), MLCP- Mulberry leaves chutney powder (10per cent).

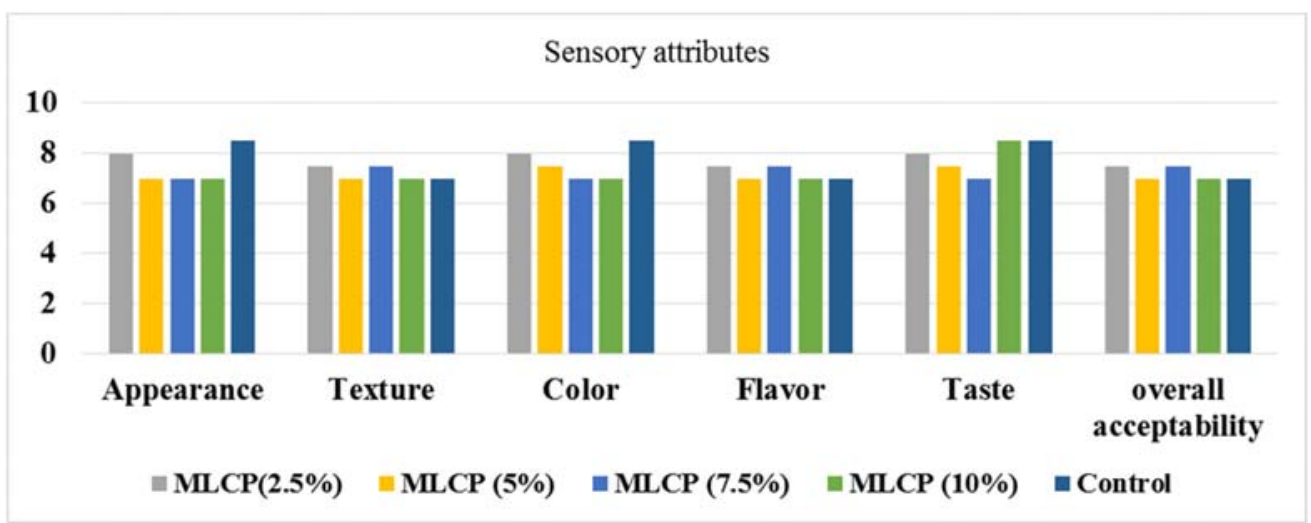

MLCP- Mulberry leaves chutney powder (2.5\%), MLCP- Mulberry leaves chutney powder (5\%),

MLCP- Mulberry leaves chutney powder (7.5\%), MLCP- Mulberry leaves chutney powder (10\%),

Fig 7: Mean sensory score of Mulberry leaves chutney powder

\section{Proximate composition of Chutney powder}

The above results are differing with the study conducted by Shwetha (2009) who developed chutney powder with incorporation of mulberry leaves powder at 2 and 5 per cent. The product was evaluated for sensory characteristics like appearance, texture, taste and overall acceptability, their results showed that incorporation of 5 per cent of mulberry leaves powder was acceptable than other variations. This may be due to proportion of other ingredients used and also method of preparation during the study.

Proximate composition of mulberry leaves chutney powder The proximate composition like moisture, fat, fibre, ash, carbohydrate and energy of control and highly accepted mulberry leaves chutney powder had been analysed and depicted in Table 3. It was found that proximate compositions varied significantly compared to the control.

It was found that Mulberry leaves chutney powder at 2.5 per cent (MLCP) had significantly higher Protein (11.2 g), fat
(12.2 g), fibre (6.8 g) than control chutney powder i.e., (9.69g, $11.83 \mathrm{~g}$, fibre $6.8 \mathrm{~g}$ respectively), carbohydrate $(61.98 \mathrm{~g})$ and energy $(393.15 \mathrm{kcal})$ in control. which was found highest in control, where ash did not differ significantly.

Table 3: Proximate composition of chutney powder

\begin{tabular}{|c|c|c|c|}
\hline Proximate & Control & MLCP (2.5 \%) & t value \\
\hline Moisture (\%) & 3.3 & 2 & $18.74^{*}$ \\
\hline Protein $(\mathrm{g})$ & 9.69 & 11.72 & $88.33^{*}$ \\
\hline Fat $(\mathrm{g})$ & 11.83 & 12.2 & $3.4^{*}$ \\
\hline Fibre $(\mathrm{g})$ & 6.8 & 7.6 & $3.09^{*}$ \\
\hline Ash $(\mathrm{g})$ & 6.4 & 6.46 & - \\
\hline CHO (g) & 61.98 & 59.02 & $14.58^{*}$ \\
\hline Energy (Kcal) & 393.15 & 390.36 & $43.47^{*}$ \\
\hline
\end{tabular}

T test- NS- non significant,

* Significant, MLCP- mulberry leaves chutney powder.

These results are in good harmony with the study conducted by Balaswamy et al., (2004) ${ }^{[2]}$. 
Balaswamy et al. (2004) ${ }^{[2]}$ taken up studies to standardize the recipe for the preparation of curry leaf chutney powder using curry leaves (Murraya koenigii L.) and spice mix The chutney powder was analysed for their physicochemical characteristics. The physico-chemical composition of accepted curry leaf chutney powder contains total ash of (4.0 per cent), Crude fibre of (7.0 per cent), total protein of (16.4 per cent), crude fat of (14.2 per cent) and energy value of 370 $\mathrm{kcal} / 100 \mathrm{~g}$.

\section{Mineral composition of Chutney powder}

Nutritionally caused iron deficiency, iodine deficiency disorders, blindness and anaemia are some of the major problems of micro-nutrient deficiency seen especially in vulnerable group of population (Shanthala et al. 2005). Food based approaches is one of the measures to prevent malnutrition among the population, which concentrate on improvement or change in food habits by creating awareness among the population (FAO, 1996-1997) ${ }^{[4,5]}$.

The difference in characteristics viz. zinc, iron, manganese, copper among the variations was found to be statistically significant at 5 per cent level.

Chutney powder prepared using different levels of mulberry leaves were prepared and best accepted sample was analysed for mineral composition and depicted in Table 4, were mulberry leaves chutney powder (MLCP) at 2.5 per cent contain zinc $(4.8 \mathrm{mg})$, iron $(15.44 \mathrm{mg})$, manganese $(2.74 \mathrm{mg})$, copper $(2.72 \mathrm{mg})$ and calcium $(2.63 \mathrm{mg})$. where as in control zinc (4.5 mg), iron (9.82 $\mathrm{mg})$, copper $(1.28 \mathrm{mg})$, manganese $(2.06 \mathrm{mg})$ and calcium $(1.16 \mathrm{mg})$. The increase in mineral composition of products prepared using mulberry leaf powder is due to more amount of micro nutrients present in mulberry leaves. where dehydration of mulberry leaves may also increase the mineral content of products.

Table 4: Mineral composition of Chutney powder

\begin{tabular}{|c|c|c|c|}
\hline Micro nutrients (mg) & Control & MLCP (2.5 \%) & t value \\
\hline Zinc & 4.5 & 4.8 & $5.9^{*}$ \\
\hline Iron & 9.82 & 15.44 & $36.63^{*}$ \\
\hline Manganese & 2.06 & 2.74 & $18.19^{*}$ \\
\hline Copper & 1.28 & 2.72 & $33.9^{*}$ \\
\hline Calcium & 1.16 & 2.63 & $41.6^{*}$ \\
\hline
\end{tabular}

T test- NS- non significant,

* significant, MLCP- mulberry leaves chutney powder.

Balaswamy et al. (2004) ${ }^{[2]}$ taken up studies to standardize the recipe for the preparation of curry leaf chutney powder using curry leaves (Murraya koenigii L.) and spice mix. The results revealed that chutney powder prepared with curry leaves contains significant amount of minerals, viz., calcium (1.27 $\mathrm{mg})$, iron $(9.3 \mathrm{mg})$ and copper $(0.56 \mathrm{mg})$.

\section{Anti-nutrient content of chutney powder}

The anti-nutrients in chutney powder like phytates among the variations differed significantly. Where oxalate and tannin were non-significant.

The best accepted treatment where chutney powder containing 2.5 per cent mulberry leaf was analysed for antinutrient along with control. Control chutney powder contain phytic acid about (114.2 mg), oxalic acid content (31.98 mg) and tannin content $(0.6085 \mathrm{mg})$, where chutney powder prepared using mulberry leaf at 2.5 per cent containing phytic acid $(110.75 \mathrm{mg})$, oxalates $(30.78 \mathrm{mg})$ and tannin $(0.595$ $\mathrm{mg}$ ). Here the less amount of anti-nutrients was observed in the products it may be due to less anti-nutrient content of mulberry leaves and processing may reduce the anti-nutrients of leaves during product preparation. Anti-nutrient content of Chutney powder prepared using mulberry leaf is presented in Table 5.

Table 5: Anti-nutrient contents of chutney powder

\begin{tabular}{|c|c|c|c|}
\hline Anti-nutrients & Control & MLCP (2.5 \%) & t value \\
\hline Phytates (mg/100g) & 114.2 & $110.75^{*}$ & $2.27^{*}$ \\
\hline Oxalates (mg/100g) & 31.98 & 30.78 & $9.41^{*}$ \\
\hline Tannin(mg/100g) & 0.6085 & 0.595 & - \\
\hline
\end{tabular}

T-test-*Significance, NS- Non significant at 5per cent level, MLCPMulberry leaves chutney powder (2.5 per cent), Control- with no mulberry leaf.

The results obtained in the present study on anti-nutrient content differ with Mamatha and Jamuna Prakash (2016) ${ }^{[6]}$ in this study instant powders like puliyogare, Rasam, Bisibele bath, and sambar powder prepared using tamarind powder. Sambar powder was evaluated for anti-nutrient contents where sambar powder contains phytic acid (122.2g) and oxalates $(156.5 \mathrm{~g})$.

\section{Cost of production of best accepted mulberry leaves chutney powder}

The production cost of the best accepted mulberry leaves chutney powder ( 2.5 per cent) and control without mulberry leaves was calculated and depicted in the Table 6 . The cost of raw material for control was 9.85 and chutney powder prepared with mulberry leaves was 9.28 , production cost for control is 2.94 and for best accepted one is 2.78 and selling price for 100 gm chutney powder for best accepted one was Rs.16.73 and for control was Rs.18.085 respectively. Where the cost of best accepted chutney powder is less than control.

Table 6: Production cost of mulberry leaves chutney powder (per $100 \mathrm{~g})$

\begin{tabular}{|c|c|c|c|c|c|}
\hline \multirow[b]{2}{*}{ Ingredients } & \multirow[b]{2}{*}{$\begin{array}{l}\text { Ingredients } \\
\text { cost/kg }\end{array}$} & \multicolumn{2}{|c|}{ Control } & \multicolumn{2}{|c|}{2.5 per cent } \\
\hline & & \begin{tabular}{|c|}
$\begin{array}{c}\text { Ingredients } \\
\text { used (g) }\end{array}$ \\
\end{tabular} & \begin{tabular}{|c|}
$\begin{array}{c}\text { Price } \\
\text { Rs }\end{array}$ \\
\end{tabular} & \begin{tabular}{|c|}
$\begin{array}{c}\text { Ingredients } \\
\text { used (g) }\end{array}$ \\
\end{tabular} & \begin{tabular}{|c|} 
Price \\
Rs
\end{tabular} \\
\hline \multicolumn{6}{|c|}{ A. Raw material cost/kg (Total) } \\
\hline $\begin{array}{c}\text { Mulberry } \\
\text { leaves }\end{array}$ & 20 & - & - & 2.5 & 0.05 \\
\hline Uradh dhal & 100 & 30 & 3 & 30 & 3 \\
\hline Chana dhal & 70 & 30 & 2.1 & 30 & 2.1 \\
\hline Red gram & 100 & 20 & 2 & 18 & 1.8 \\
\hline Dry coconut & 210 & 11 & 2.31 & 10.5 & 1.89 \\
\hline Chillies & 160 & 3 & 0.18 & 3 & 0.18 \\
\hline Garlic & 40 & 2 & 0.08 & 2 & 0.08 \\
\hline Tamrind & 70 & 2 & 0.14 & 2 & 0.14 \\
\hline Salt & 2 & 2 & 0.04 & 2 & 0.04 \\
\hline Yield (g) & & 100 & - & 100 & - \\
\hline \multicolumn{2}{|c|}{ Total cost Raw material } & & 9.85 & & 9.28 \\
\hline \multicolumn{2}{|c|}{$\begin{array}{l}\text { B. Production cost including } \\
\text { machinery and labour cost @ } \\
30 \text { per cent of raw material } \\
\text { cost }\end{array}$} & - & 2.943 & - & 2.78 \\
\hline \multicolumn{2}{|c|}{ Sub total } & & 12.24 & & 12.064 \\
\hline \multicolumn{2}{|c|}{$\begin{array}{c}\text { C. Institutional charges @ } 10 \\
\text { per cent }(\mathrm{A}+\mathrm{B})\end{array}$} & - & 2.205 & - & 1.206 \\
\hline \multicolumn{2}{|c|}{ Sub total } & & 14.445 & & 13.27 \\
\hline \multicolumn{2}{|c|}{$\begin{array}{l}\text { D. Profit @10 per cent } \\
(\mathrm{A}+\mathrm{B}+\mathrm{C})\end{array}$} & - & 3.64 & - & 3.46 \\
\hline \multicolumn{2}{|c|}{ Cost per $100 \mathrm{~g}$} & & 18.085 & & 16.73 \\
\hline
\end{tabular}

\section{Conclusion}

Orally chutney powder prepared using mulberry leaves at 2.5 per cent has been best accepted and it has highest proximate and mineral composition with less anti-nutrients compared to 
control hence it can be used in our daily diet as a nutrient rich product.

\section{References}

1. AOAC. Official methods of analysis, 13th edition. Association of official agricultural chemists, Washington, D. C., 1980-2004.

2. Balaswamy K, Jyothirmayi T, Rao DG. Studies on preparation of curry leaf (Murraya koenigii L.) Chutney powder. Food ser. Res. Inter. 2004; 14(1):175-187.

3. Baljeet SY, Ritica BY, Roshan LY. Studies on functional properties and incorporation of buckwheat flour for biscuits. Int. Food Res. J. 2010; 17(1):1067-1076.

4. FAO. Scientific considerations in development of food based dietary guidelines. Report of a Joint FAO/WHO consultation, Geneva, Switzerland, 1996.

5. FAO. Preventing Micronutrient Malnutrition. A guide to food-based approaches. Food and Agricultural Organization and International Life Science Institute, Washington, DC, 1997.

6. Prakash J, Gupta S. utilization of micronutrient-rich dehydrated green leafy vegetables in Formulation of traditional products. Int. food res. J. 2016; 33(1):35-43.

7. Islampure S. Nutritional evaluation and glycaemic Index of selected varieties of mulberry leaves. Thesis (M.Sc.), Unpublished, University of Agricultural Sciences, GKVK, Bangalore, 2015, 70. 